Discussion Paper No. 18-037

Training in the Great Recession Evidence from an Individual Perspective

Daniel Dietz and Thomas Zwick

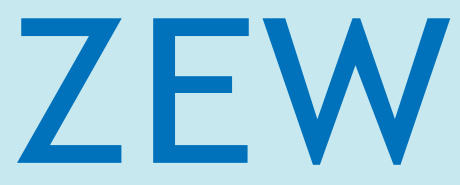

Zentrum für Europäische Wirtschaftsforschung $\mathrm{GmbH}$

Centre for European

Economic Research 
Discussion Paper No. 18-037

\section{Training in the Great Recession - Evidence from an Individual Perspective}

Daniel Dietz and Thomas Zwick

Download this ZEW Discussion Paper from our ftp server:

http://ftp.zew.de/pub/zew-docs/dp/dp18037.pdf

Die Discussion Papers dienen einer möglichst schnellen Verbreitung von neueren Forschungsarbeiten des ZEW. Die Beiträge liegen in alleiniger Verantwortung der Autoren und stellen nicht notwendigerweise die Meinung des ZEW dar.

Discussion Papers are intended to make results of ZEW research promptly available to other economists in order to encourage discussion and suggestions for revisions. The authors are solely responsible for the contents which do not necessarily represent the opinion of the ZEW. 


\title{
TRAINING IN THE GREAT RECESSION - EVIDENCE FROM AN INDIVIDUAL PERSPECTIVE ${ }^{1}$
}

Daniel Dietz (University of Wuerzburg) and Thomas Zwick (University of Wuerzburg and ZEW, Mannheim)

\begin{abstract}
:
This paper analyses the effect of the economic crisis in 2008 and 2009 on individual training activities of different employee groups within establishments. We use a unique German linked employer-employee panel data set with detailed information on individual training history (WeLL-ADIAB). The so-called Great Recession can be seen as an exogenous, unexpected, and time-limited shock. Therefore, our quasi-experimental setting using Diff-in-Diff analyses reveals the causal impact of the crisis on the training participation and the number of training measures. We find a direct negative effect of the crisis on individual training activities in 2009 and 2010. The negative effect therefore sets in with a time lag and lasts until after the recession. Furthermore, the recession effect is stronger for employees in unskilled jobs than for employees in skilled jobs.
\end{abstract}

JEL-Classification: M53, O16

Keywords: Training, Financial Crisis, Linked Employer Employee Data Set

\footnotetext{
${ }^{1}$ We use the anonymized 'Berufliche Weiterbildung als Bestandteil lebenslangen Lernens' ('Further Training as a Part of Lifelong Learning', WeLL) data set provided by the Research Data Centre (FDZ) of the Federal Employment Agency at the Institute for Employment Research (IAB). Data access was via guest research spells at FDZ and afterwards via controlled remote data access at FDZ (project number 603). We thank Alexandra Schmucker and Stefan Bender for advice with data preparation and interpretation and Boris Hirsch, Susanne Steffes as well as Arne Warnke for useful comments on earlier versions of this paper.
} 


\section{Introduction}

Further training in Germany is market driven and investment decisions are mainly taken and funded by the establishments (Bender et al., 2008a). Training firms expect productivity gains at the individual and establishment levels (Zwick, 2005) and aim to recoup their training investments by obtaining a difference between productivity and wages after training (Dearden et al., 2000). Training therefore might increase the competitiveness of employers. However, in economically difficult and uncertain times, credit constraints and demand reductions might induce employers to reduce training. Training investments might be reduced because of uncertain future employment needs and the lower expected tenure of trained employees. Training might also decrease when employers shift investments to more pressing areas because training investments are often expensive, their true benefits are rather hard to assess, and they may come with a lag. Firms however also might use slack periods during recessions in order to increase the share of training in total investments because their opportunity costs are temporarily low. In addition, the outside options for trained employees decrease in uncertain times and therefore the costs necessary to retain trained employees might be lower. Both arguments lead to different predictions of the consequences of recessions for training investments and competitiveness. Hence, it is important to empirically investigate how establishments' training activities are affected by a recession. As establishments' training provision often depends on the skill level of the employees (Barron et al., 1999; Blundell et al., 1999), the question also arises whether establishments' reactions in training activities are specific to certain employee groups. If less skilled employee groups are hit harder by recessions, this might be a reason for the frequently observed increase in inequality after recessions (Forster et al., 2011; Grabka, 2015; OECD, 2015).

This paper focuses on the consequences of the so-called Great Recession in the years 2008 and 2009 on training efforts of firms in Germany. This crisis was triggered primarily by the collapse of the US real estate market. In particular, the bankruptcy of the bank Lehman Brothers in late 2008 and the subsequent collapse of the interbank lending market led to a decline in demand, resulting from banks' restricted resources for lending and credit constraints (Bond et al., 2005; Ivashina and Scharfstein, 2010). In contrast to other countries, the labour market in Germany was only partially affected with mainly the export-oriented manufacturing industry being hit by demand reductions and credit constraints (Bellmann and Buttler, 2010; Möller, 2010; Hochfellner et al., 2015). Other economic sectors were hardly 
affected, however. The crisis was short, pervasive, and it came as a surprise for most politicians, managers, and employees (Bloom, 2014). We therefore do not have to take anticipation effects into account. These characteristics imply that we can use the Great Recession as quasi-natural experiment in which the training reactions of a treatment group of firms that was affected by an exogenous demand and credit shock can be compared to training activities of firms that were not affected. We use a Diff-in-Diff analysis and can therefore avoid the usual problem that unobservable third factors such as management quality or the importance of human capital for competitiveness drive both, the impact of the business cycle and firm training decisions (Hochfellner et al., 2015; Popov, 2014).

In contrast to previous research on the impact of the business cycle on training, this is the first paper to use primarily training information collected from individual employees. Thus, we can take into account that the establishments' training provision often depends on the skill level of the employees. Higher ability lowers the costs of training, which results in increasing rates of returns to training with qualification. Furthermore, higher education and skill levels help employees to adapt more rapidly to new tasks. Nevertheless, firms might also offer up-skilling to low skilled employees during a recession in order to be able to retain these employees for the next boom phase (Brunello, 2009). Based on the extensive German linked employer-employee panel data set WeLL-ADIAB, we can relate individual training information to the establishments in which the training measures took place (Bender et al., 2008a; Spengler, 2007). Our data set also includes employees without training investments. Furthermore, from the administrative establishment-level data based on the IAB Establishment Panel, information regarding the respective training establishments is available. In addition to general information about the establishment, it also includes very detailed information on the degree to which establishments were hit by the economic crisis (Fischer et al., 2008). We can observe training behaviour of the firms before, during and after the crisis because we have data from 2006-2010.

The paper is organized as follows. Chapter 2 provides the theoretical framework and derives the hypotheses. Chapter 3 presents the data set and the identification strategy. Chapter 4 outlines the estimation strategy. The results of descriptive and multivariate analyses as well as the robustness checks are shown and discussed in Chapter 5. The paper ends with a conclusion in Chapter 6. 


\section{Theoretical framework}

\section{Background discussion}

From a theoretical perspective, there is ambiguity as to whether an economic crisis leads to higher or lower training activities. In economically tough times, declines in demand often leave capacities underutilized. As the loss of working time is cheaper with idle capacities, opportunity costs of further training are lower (Aghion and Saint-Paul, 1998; Brunello, 2009). During the crisis, the outside options for trained employees are also relatively bad and therefore the risk of poaching for these employees declines. The lower exit risk of trained workers additionally reduces the opportunity costs of training (Felstead and Green, 1996; Mason and Bishop, 2015). As a consequence, establishments might have higher incentives to exempt employees from everyday work to participate in training measures. Furthermore, the possibility of participating in training even in rough times may contribute to employees' motivation and commitment (Bellmann et al., 2014). Another argument for higher training activities in a recession is that qualified employees will be more productive in the following upswing (Brunello, 2009). Keeping people in the establishment instead of dismissing them also saves adjustment costs such as dismissal costs and costs of new hiring and initial training (Horning, 1994; Knudsen and Lien, 2015; Mason and Bishop, 2015). The strategy of labour hoarding in combination with training activities is particularly important in view of the expected shortage of skilled workers and the necessity of retaining qualified employees in a boom phase (Möller, 2010).

However, economic theory also suggests that establishments may reduce training activities in times of crisis. Owing to declining sales and possible credit constraints, establishments must limit their investments in all areas (Mason and Bishop, 2015). Training costs are often very high, and their effects and benefits are generally rather hard to assess and may come with a lag (Becker, 1962). Therefore, establishments will tend to invest their limited resources in areas where short-term returns can be generated (Bellmann et al., 2014; Popov, 2014). Especially when the duration of the crisis and establishments' future prospects are difficult to predict, it is uncertain whether a return on training can be achieved at all. Training measures only become cost-effective for establishments when the marginal productivity of the trained employees is higher than their wages (Barron et al., 1997a). However, when capacity utilization is not expected to return to pre-recession levels, there may also be lower expectations regarding the impact of training on productivity (Mason and Bishop, 2015; Shury, 2010). In the case of limited commercial activities, the capabilities of trained employees cannot be fully utilized. In addition, there is lower demand for initial 
training because fewer employees are hired (Brunello, 2009). In consequence, establishments may consider further training as unprofitable and reduce their investments (Stevens, 1994).

Cost-benefit considerations of training often suggest skill levels as key drivers for the provision of training. Higher abilities of the qualified employees reduce the training costs (Blundell et al., 1999; Cohen and Levinthal, 1989). Better learning results are mainly caused by the well-established cumulative effect of knowledge acquisition. Accordingly, employees with higher levels of knowledge learn more easily (Dierickx and Cool, 1989; Hatch and Dyer, 2004). Also, Card (1999) and Heckman (1999) emphasize that higher skilled employees have higher learning abilities in further training. Higher learning abilities in turn lead to higher rates of return for trained employees with higher skills ${ }^{2}$ (Arulampalam and Booth, 2001; Barron et al., 1989). In consequence, it is more profitable for an establishment to train wellqualified employees (Bassanini and Ok, 2007; Kuckulenz and Zwick, 2004). Furthermore, skilled employees are able to adapt more rapidly and efficiently to new tasks and they are often the main source of innovation (Blundell et al., 1999). Thus, skilled employees help to better overcome an economic crisis that is associated with uncertainty and a higher need to adapt. Higher skilled employees are therefore more likely to be hoarded and trained during a recession (Hochfellner et al., 2015; Knudsen and Lien, 2015). In the decision to provide training in the crisis, establishments may also include the fact that less well-qualified employees are often less willing to participate in training (Borghans et al., 2008; Fouarge et al., 2013). This problem is caused by the fact that most low qualified employees already had negative learning experiences in school and accordingly want to avoid training in later life (Illeris, 2006). If less skilled employees are hit harder by a recession this might be one reason for the observation that earnings inequality frequently increases after recessions (Forster et al., 2011; Grabka, 2015; OECD, 2015).

\section{Previous empirical evidence}

The few studies on the impact of a recession on further training lead to contradicting results. Based on data from the US National Longitudinal Survey of Youth (NLSY), Majumdar (2007) reveals pro-cyclical training activities for the period from 1979 to 1988 . He shows that the probability of receiving training decreases with the local unemployment rate.

\footnotetext{
${ }^{2}$ Positive selection into training must be considered. It is difficult to know whether the higher earnings of better qualified employees are caused by their higher education, or whether these employees choose to acquire more training. According to this, the return on training will sometimes be overestimated (Blundell et al., 1999; Card, 1999; Heckman, 1999).
} 
This relationship is explained by better recruitment possibilities in the labour market and therefore reduced incentives for establishments to provide training. Sepulveda (2004) also uses the NLSY data from 1979 to 1998 but finds counter-cyclical training participation. The training incidence and intensity of on-the-job training and off-the-job training decrease with GDP. Using data from 15 European countries, Bassanini and Brunello (2008) also suggest a negative relationship between the proportion of employees participating in training and the economic situation. Bassanini et al. (2007) find higher training activities of establishments with unemployment rates in different European countries.

There are only a few studies analysing the effects of the Great Recession in 2008 and 2009 on the establishments' training activities. Based on different data sets and qualitative interviews from the UK, Felstead et al. (2012) find that the crisis had not a dramatic negative impact on training provision. Only a minority of establishments reduced spending per head. In many cases, establishments searched for more cost-effective ways of training and adapted these measures to their business needs (Felstead et al., 2012). In contrast, Popov (2014) stresses that limited access to financial resources and bank credit is associated with significantly lower training investments. Analysing survey data on small and medium-sized establishments from 25 transition economies, he also reveals stronger negative effects in education-intensive sectors and in sectors with good global growth potential (Popov, 2014). Based on the IAB Establishment Panel, Bellmann et al. (2014) find that German establishments reduced their training activities in 2009 - at the peak of the crisis - compared with 2008, independently of whether or not they have been directly affected by the economic crisis. In addition, establishments that have been directly affected by the crisis reduced their training efforts to a much larger extent than other establishments. The studies on the current economic crisis suggest a negative impact on training activities. However, they do not permit separate observations of training participation for different employee groups. Only Mason and Bishop (2015) differentiate the impact of the recession on training for employee groups. Based on longitudinal data from Employer Skills Updating Surveys in the UK, they find that the downturn has contributed to reductions in training especially for off-the-job training and for skilled and highly skilled employees. On-the-job training was reduced slightly and stronger targeted at employees with identified skill improvement needs. The employers were however just asked about training needs and not about the actual training participation of their employees. Therefore, employers may have an interest in reporting training statistics to their advantage. 
Hochfellner et al. (2015) provide the only analysis that examines the impact of the recent crisis on individual-level outcomes such as earnings, unemployment probability and mobility. Based on a linked employer-employee data set for Germany, they show that unskilled, less educated and less experienced employees are most negatively affected by financial shocks in the downturn. In contrast, employees in the higher skill categories are able to mitigate these shocks. As a result, the crisis increases the existing income differentials between the employee groups. However, this study does not consider training information.

\section{Hypotheses}

From the theoretical perspective, it is not clear whether difficult economic times lead to higher or lower establishment training activities. There is empirical evidence for training being counter-cyclical (Sepulveda, 2004) or pro-cyclical (Bassanini et al., 2007; Bassanini and Brunello, 2008; Majumdar, 2007). However, all studies that have analysed the effects of the Great Recession find negative effects on establishments' training activities (Bellmann et al., 2014; Felstead et al., 2012; Mason and Bishop, 2015; Popov, 2014). The recession in addition came as a shock and incurred strong uncertainty on the future development (Bloom, 2014). Our assumptions therefore are:

$H_{1}:$ When establishments are negatively affected by the Great Recession, the training participation of their employees decreases.

$\mathrm{H}_{2}$ : When establishments are negatively affected by the Great Recession, the number of training measures offered decreases.

In the context of training decisions, for establishments, cost-benefit considerations are decisive. Training only becomes effective when employees' post-training benefits are greater than their costs and establishments achieve positive rates of return (Barron et al., 1997a; Becker, 1962). Owing to the limited financial resources, returns of training are essential in times of crisis. Training theory suggests higher returns of training and higher expected values for skilled training participants (Arulampalam and Booth, Barron et al., 1989, 1999; Card, 1999). Furthermore, because they can better adapt to changes in the environment, skilled employees help to better overcome the crisis and the uncertainty it incurs (Blundell et al., 1999). According to Hochfellner et al. (2015), less skilled employees are more negatively 
affected by the Great Recession and face a stronger decline in salary and job losses. We therefore assume:

$H_{3}$ : When establishments are negatively affected by the recession, the training participation of unskilled employees decreases stronger than training participation of skilled employees.

$H_{4}$ : When establishments are negatively affected by the recession, they stronger reduce the number of training measures for unskilled employees than for skilled employees.

\section{Data and identification strategy}

We use the German linked employer-employee panel data set WeLL-ADIAB. The data set is based on a survey of 149 establishments that were selected from the 2005 wave of the IAB Establishment Panel $^{3}$. From these establishments, 7,352 randomly selected employees were asked in four annual waves ${ }^{4}$ about their individual training behaviour between 2007 and 2010. Training information includes the start and end dates, the duration as well as the thematic focus of the measures. An advantage of the data set is the linkage of the individual training information with administrative data at individual and establishment level (Bender et al., 2008a; Spengler, 2007; Dietz and Zwick, 2016). Thus, in addition to sociodemographic information (age, sex, occupational status), the complete individual employment history ${ }^{5}$ for training participants and non-participants is available (Schmucker et al., 2014). Furthermore, based on the linkage of individual information with establishment-level data from the IAB Establishment Panel, it is also possible to assign the training information to the establishment where the training took place. In addition to information about the establishment that might be related to training provision (size, sector, location), we also have

\footnotetext{
${ }^{3}$ In the selection process, only establishments from manufacturing or the service industry located in the German federal states of Bavaria, Schleswig-Holstein and North Rhine-Westphalia, Mecklenburg-Western Pomerania and Saxony and establishments with between 50 and 1,999 employees were considered (Bender et al., 2008b and Knerr et al., 2012). As the selection of establishments did not occur randomly, the data set cannot claim to be representative of the population of German establishments.

${ }^{4}$ The first wave contains the complete training information for the years 2006 and 2007, the second wave the training information for the year 2008, the third wave for 2009 and the fourth wave for 2010 .

5 The employment history includes start and end dates of employment periods, the exact daily wage in the respective periods, further characteristics of employment (e.g. occupation, job status, working time) and unemployment spells. This information has been collected for social insurance reasons by administrative institutions and is therefore highly reliable (Bender et al., 2009; Schmucker et al., 2014).
} 
detailed information on the degree to which the establishment was hit by the economic crisis (Fischer et al., 2008).

The training information and all individual data therefore come from the employees and the crisis information originates from the establishments. This combination has the advantage that employees can provide much more detailed and reliable information on their educational and employment biographies as well as on certain training measures than their employers. Although the training measures are offered by establishments, it is often unclear for the management to what extent employees participate in them. In addition, separating the source of training data from the source of crisis information also helps us to avoid common method bias. Another problem the literature on the impact of recessions on training provision faces is that it is often hard to observe when and how establishments are affected by a recession and how the causality runs between business cycle and training. More specifically, it is usually hard to exclude unobservable third factors such as higher manager quality or better growth opportunities that influence both, the risk of the firm to be hit by a recession and its training behaviour (Popov, 2014). Endogeneity therefore might bias the estimated relationship between a recession and training efforts. In order to avoid this problem, a crisis must be exogenous in the sense that it affects firms independently of their training strategy and other factors related to training behaviour.

A recession often is the result of unanticipated changes in the environment, such as bursting bubbles in the property or stock market or dramatic changes in commodity prices. Thus, the beginning of such a crisis can be seen as an exogenous shock for establishments and the entire economy (Knudsen and Lien, 2015). In addition, a recession is temporary ${ }^{6}$, and establishments know that it will be over sooner or later (Koberg, 1987). The economic crisis in 2008 and 2009 in addition was unpredictable. Therefore, the Great Recession can be seen as an exogenous shock and anticipation effects of firms can be mainly excluded.

Previous empirical studies investigating the impact of the current financial crisis use different identification strategies. Felstead et al. (2012) as well as Mason and Bishop (2015) identify the crisis by means of time. They assume that 2008 is a pre-crisis period, 2009 during the crisis and 2010 after the crisis. However, both studies do not differentiate between affected and unaffected establishments. Furthermore, they are not able to rule out that training efforts as well as the involvement in the crisis may be influenced by unobservable third

\footnotetext{
${ }^{6}$ This distinguishes a recession from a technological shock that leads to permanent changes in the economy (Knudsen and Lien, 2015).
} 
factors (Popov, 2014). In order to avoid this endogeneity problem, Popov (2014) and Hochfellner et al. (2015) apply Diff-in-Diff approaches. In addition, Hochfellner et al. (2015) exploit an institutional feature of the German banking system to identify a control group that serves as a plausible counter-factual on the basis of German states. Despite their convenient empirical setting, it is unclear whether all establishments in the states with a Landesbank suffering from credit constraints are affected by the crisis. To identify affected establishments, Bellmann et al. (2014) therefore use information from the 2010 wave of the IAB Establishment Panel. Based on self-assessments, establishments were asked whether and to what extent they were affected by the Great Recession.

We also apply Bellmann et al.'s (2014) identification strategy. Based on the questions 'have you been affected by the economic crisis in the last two years?' and 'were the effects on your establishment predominantly negative?', we calculate a dummy variable that is equal to one if the establishments agree to both questions; otherwise, the crisis dummy is 0 . In the 2010 wave of the Establishment Panel, there are 78 establishments with information about the crisis. Of these, 40 establishments ${ }^{7}$ claimed that they had been negatively affected by the crisis and these are henceforth referred to as crisis establishments. Another 30 companies stated that they were not affected by the crisis and they are referred to as non-crisis establishments ${ }^{8}$.

In addition, we test and compare the classification of crisis and non-crisis establishments with other crisis indicators. Applying the identification strategy of Hochfellner et al. (2015), most of the establishments in the states in which the regional Landesbanks were affected by the crisis also claimed to be crisis establishments in our data set. Furthermore, we compare the business expectations of crisis and non-crisis establishments over time. Although there are no differences in expected business volume in 2006, 2007 and 2010, the business expectations of crisis establishments were more negative in 2008 and 2009 that those of noncrisis establishments. Crisis establishments have fewer employees and they are found especially in manufacturing industry, compare Bellmann et al. (2014) and Hochfellner et al. (2015). ${ }^{9}$

\footnotetext{
${ }^{7}$ The crisis/non-crisis classification of the establishments is fixed and does not change over time. However, 11 of our 40 crisis companies reported that they had overcome the crisis in 2010. Therefore, these establishments switch from crisis to non-crisis establishments in the year 2010. The other establishments keep their status.

${ }^{8}$ The remaining eight establishments were eliminated from the sample because they indicated that they had been affected both positively and negatively by the crisis.

${ }^{9}$ Due to the data protection agreement with the IAB no descriptive results can be presented at the operational level for both crisis and non-crisis establishments.
} 
From the 40 crisis and 30 non-crisis establishments, we have detailed information of 2,398 employees. Only employees with jobs covered by social security contributions ${ }^{10}$ are included in the sample. Furthermore, in order to obtain a homogeneous sample, we eliminated 442 employees who worked short-time ${ }^{11}$. Thus, the sample consists of 5,983 observations from 1,956 individuals. As employment spells and training spells are measured on a daily and monthly basis, respectively, we know whether training measures for skilled and unskilled employees have taken place in an establishment that was affected by the crisis or not.

\section{Estimation strategy}

The main goal of this paper is the identification of the causal effect of the crisis on establishments' individual training activities. The training activities of individuals must be compared not only between crisis establishments and non-crisis establishments, but also before, during and after the crisis. An experimental design such as the Difference-inDifferences specification (Diff-in-Diff) achieves such a comparison. The changes in training effort in the control group are subtracted from the changes in the treatment group. In this way, distortions between control and treatment group resulting from fundamental differences in both groups as well as distortions resulting from temporal trends can be removed (Angrist and Pischke, 2009; Wooldridge, 2009). As already described in the identification strategy, the Great Recession can be seen as an exogenous, unanticipated and random shock for establishments and the training activities of their employees. By using the Diff-in-Diff approach, it is therefore possible to control for endogeneity and time-invariant unobserved heterogeneity between crisis and non-crisis establishments. Using $i$ to index an individual, $j$ an establishment and $t$ the time, we specify the following estimation model:

$$
y_{i j t}=\beta_{0}+C_{i j} * T^{\prime}{ }_{t} \beta_{1}+C_{i j} \beta_{2}+T^{\prime}{ }_{t} \beta_{3}+X^{\prime}{ }_{i j t} \beta_{4}+Z^{\prime}{ }_{i j t} \beta_{5}+\varepsilon_{i j t}
$$

Focusing on the individual perspective, the dependent binary variable $y_{i j t}$ takes the value of 1 if an employee $i$ participates in training offered by the training establishment $j$ in the respective year $t$. Otherwise, the variable takes the value 0 . In addition, we take the

\footnotetext{
${ }^{10}$ Apprentices, people in internships and employees in partial retirement have been excluded from the sample.

${ }^{11}$ Many contributions pointed to a strong increase of short-time work during the recessions and the strong incentives of employers to provide training for employees working short-time (Brenke et al., 2013). In order to avoid biased results from this additional channel between recession and training, we exclude short-time work in the main analysis and run a robustness check later.
} 
number of individual training measures ${ }^{12}$ per year into account. For the research question, it is important to know when and in which establishment the training measure took place. Therefore, we eliminate all training measures that have no detailed information concerning their start and end dates and that could not be clearly assigned to an establishment (126 eliminations). In addition, we only consider training measures that are financed (at least partially) by the establishment.

The binary variable $C_{i j}$ indicates whether an establishment was hit by the economic crisis $\left(C_{i j}=1\right)$ or not. The binary variable $T^{\prime}{ }_{t}$ reflects the cyclical differences in training activities over time with a vector of time dummies for the years 2006 to 2010. The interactions of the two variables $C_{i j} * T^{\prime}{ }_{t}$ can be interpreted as the differences in the development of individual training activities over time between employees in crisis and noncrisis establishments. We have four Diff-in-Diff dummies: the interactions of the years 2007 to 2010 with $C_{i j}$. Given the unexpected exogenous shock of the crisis, prior to the occurrence of this shock, the development of training effort should be the same for crisis and non-crisis establishments. In order to verify this identification assumption, a placebo test should indicate no significant interaction effect for the pre-crisis period (Bellmann et al., 2014).

In addition to the crisis information, further individual- and establishment-level characteristics are considered that may influence training participation and the likelihood of being affected by the crisis simultaneously. Empirical evidence suggests lower training participation especially for women and older employees with higher tenure and work experience (Blundell et al., 1996; Picchio and Van Ours, 2013). In contrast, higher qualified employees have a higher probability of participating in training (Arulampalam and Booth, 2001; Card, 1999; Gritz, 1993). In addition, it is known that employees with higher work experience are less affected by the crisis (Hochfellner et al., 2015). Therefore, the individual characteristics vector $X^{\prime}{ }_{i j t}$ includes the variables gender, age, occupational status ${ }^{13}$, tenure, and work experience ${ }^{14}$. Studies focusing on establishment-level determinants of training find that especially employees in larger establishments have a higher probability of receiving training. Furthermore, the sector and the location of the establishment have an impact on the

\footnotetext{
${ }^{12}$ In order to ensure consistency, we limit the maximum number of training measures per year to 12 and delete four observations with additional information.

${ }^{13}$ If we use highest educational attainment as an indicator for skill level instead of occupational status, we obtain the same results.

${ }^{14}$ Age is measured as a cohort effect for the following birth year groups: birth year before 1951, between 1952 and 1961, between 1962 and 1971 and after 1972. For the two variables tenure and work experience, in each case, we use the classification less than 10 years, between 10 and 20 years and more than 20 years of tenure or experience.
} 
likelihood of training (Bellmann and Gerner, 2011; Gerlach and Jirjahn, 2001; Holtmann and Idson, 1991; Lynch, 1991). At the same time, these establishment characteristics may also influence the likelihood of being affected by the crisis. Bellmann et al. (2014) and Möller (2010) for example find that the crisis mainly affected larger establishments from the manufacturing sector. The establishment characteristics vector $Z^{\prime}{ }_{i j t}$ therefore includes the variables establishment size, sector and location ${ }^{15}$. The symbol $\varepsilon_{i j t}$ reflects an idiosyncratic error term.

We estimate a linear probability model explaining individual training participation and a linear regression model explaining the number of training measures. In order to gain insights into whether employees with specific characteristics are affected differently by the economic crisis, the sample is also subdivided into skilled and unskilled employees. We argue that the topical job is a more important determinant for training participation than the highest schoolleaving qualification and therefore we use occupational position ${ }^{16}$ as indicator for skills. We differentiate between employees in unskilled and semi-skilled jobs ("unskilled jobs") and all other jobs ("skilled jobs"). For the separate samples, we estimate identical regression models for each training indicator. In addition, we test the significance of the differences between the coefficients of interest in the two samples using a $\mathrm{Chi}^{2}$ test. The standard errors were adjusted using a robust, cluster-adjusted sandwich estimator. As clustering is carried out at the individual and the establishment level, it is possible to control for correlated observations within the individuals and the establishments (Moulton, 1990).

\section{Findings}

\section{Descriptive statistics}

Table 1 shows descriptive sample characteristics of individuals employed in crisis and non-crisis establishments. Most participants are male (64.62\%), born between 1952 and 1971 $(61.62 \%)$, and work in a skilled job (84.74\%). Although $78.63 \%$ have more than 10 years of professional experience, only $53.48 \%$ have been working in the same establishment for more than 10 years. Looking at the characteristics of employees in crisis and non-crisis establishments, there are only few differences between the two groups. Significantly fewer women and employees in skilled jobs are employed in crisis establishments. However, these

\footnotetext{
${ }^{15}$ As a result of the selection process, only establishments from manufacturing and the service industry with a maximum of 1,999 employees were available in the data set. The establishment size is classified as less than 199, between 200 and 499 and between 500 and 1,999 employees. The location is captured with a dummy, indicating Western or Eastern Germany.

${ }^{16}$ We use the Stellung im Beruf (stib) variable in the data set.
} 
differences might be a consequence of the fact that the crisis establishments are more likely to be in the manufacturing sector. In addition, employees in non-crisis establishments have a slightly higher income, highest educational attainment, and occupational status.

Employees in non-crisis establishments have a higher probability of participating in further training (70.29\%) and a higher average number of training measures (1.37) per year than employees in crisis establishments (60.89\%/1.11 measures). Figure 1 shows the development of training participation and the number of training measures over the observation period. In principle, a decline can be observed for both training indicators in all establishments. For employees in non-crisis establishments, the probability of participating in training declines slightly in 2008 and otherwise remains constant between 2006 and 2009 . However, there is a decline in the year 2010. In contrast, there is a sharp and continuous decline in the training probability for employees in crisis establishments from 2008 onwards. A similar picture emerges for the development of the number of training measures. It only declines slightly in 2008 and 2009 and then more sharply in 2010 in non-crisis establishments. Employees in crisis establishments experience a strong and continuous decline in the number of trainings between 2008 and 2010. Thus, the training activities of employees in crisis-affected establishments are more negatively affected than those of employees in unaffected establishments. 
Table 1: Description of differences of employees in crisis and non-crisis establishments

\begin{tabular}{|c|c|c|c|c|}
\hline $\begin{array}{l}\text { Socio-demographic } \\
\text { indicators }\end{array}$ & $\begin{array}{c}\text { Total } \\
\%\end{array}$ & $\begin{array}{c}\text { Crisis } \\
\text { establishments } \\
\%\end{array}$ & $\begin{array}{c}\text { Non-crisis } \\
\text { establishments } \\
\%\end{array}$ & t-values \\
\hline$\overline{\text { Female }}$ & 35.38 & 23.31 & 41.72 & $14.49 * * *$ \\
\hline \multicolumn{5}{|l|}{ Birth year } \\
\hline$\leq 1951$ & 14.67 & 13.67 & 15.20 & 1.63 \\
\hline $1952-61$ & 34.41 & 35.56 & 33.80 & -1.37 \\
\hline 1962-71 & 27.21 & 28.52 & 26.51 & $-1.67 *$ \\
\hline$\geq 1972$ & 23.71 & 22.25 & 24.49 & $1.93^{*}$ \\
\hline \multicolumn{5}{|l|}{ Experience } \\
\hline$<10$ years & 21.37 & 19.44 & 22.39 & $2.67 * * *$ \\
\hline 10-20 years & 48.64 & 51.89 & 46.92 & $-3.68 * * *$ \\
\hline$>20$ years & 29.99 & 28.67 & 30.69 & 1.63 \\
\hline \multicolumn{5}{|l|}{$\underline{\text { Tenure }}$} \\
\hline$<10$ years & 46.52 & 46.86 & 46.34 & -0.39 \\
\hline 10-20 years & 39.06 & 41.46 & 37.80 & $-2.78 * * *$ \\
\hline$>20$ years & 14.42 & 11.68 & 15.86 & $4.41^{* * *}$ \\
\hline \multicolumn{5}{|l|}{ Occupational status } \\
\hline Unskilled job & 15.26 & 25.04 & 10.13 & $-15.65 * * *$ \\
\hline Skilled job & 84.74 & 74.96 & 89.87 & $15.64 * * *$ \\
\hline Log daily wage & 4.63 & 4.58 & 4.64 & $5.21 * * *$ \\
\hline Training participation & 67.05 & 60.89 & 70.29 & $7.44 * * *$ \\
\hline $\begin{array}{l}\text { Number of training } \\
\text { measures per year }\end{array}$ & 1.28 & 1.11 & 1.37 & $6.48 * * *$ \\
\hline Observations & 5,983 & 2,089 & 3,894 & \\
\hline Individuals & 1,956 & 734 & 1,222 & \\
\hline Establishments & 70 & 40 & 30 & \\
\hline
\end{tabular}

( $\log$ ) daily wage is measured as the logarithmic weighted daily wage; *Statistically significant at the .10 level; **at the .05 level; *** at the .01 level. Source: WeLL-ADIAB 2006-2010. 


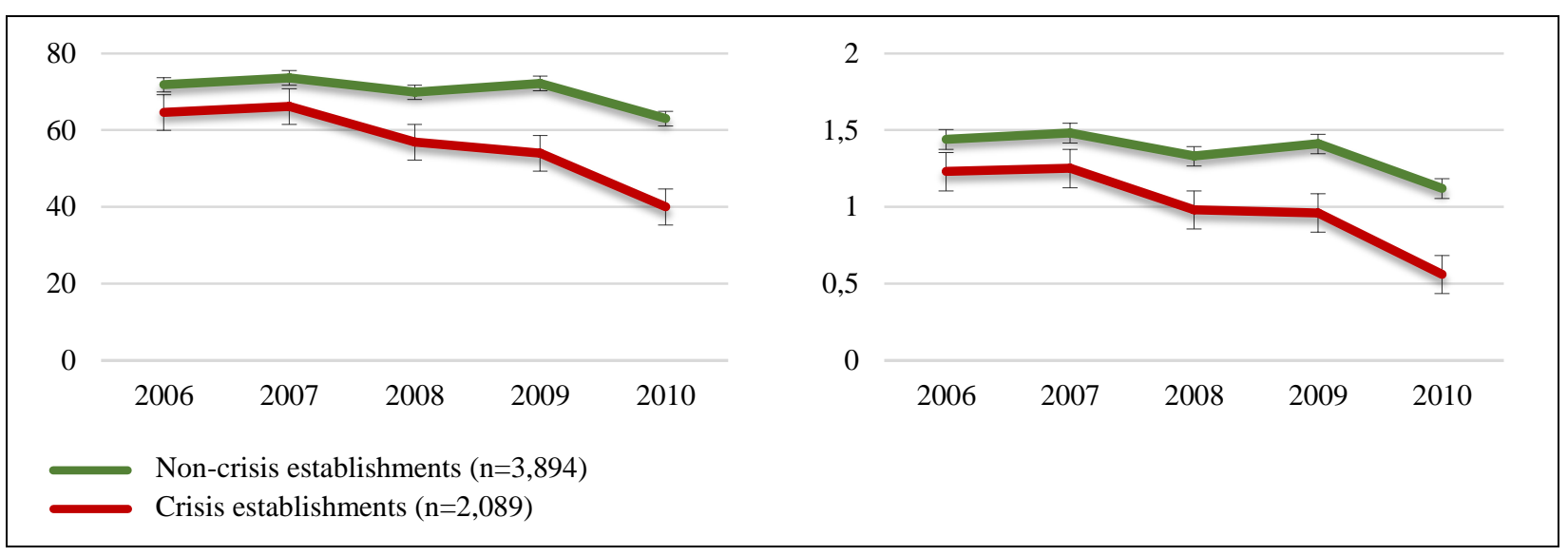

Figure 1: Development of the training participation in $\%$ (left) and the number of training measures (right) in crisis and non-crisis establishments. Standard errors are included

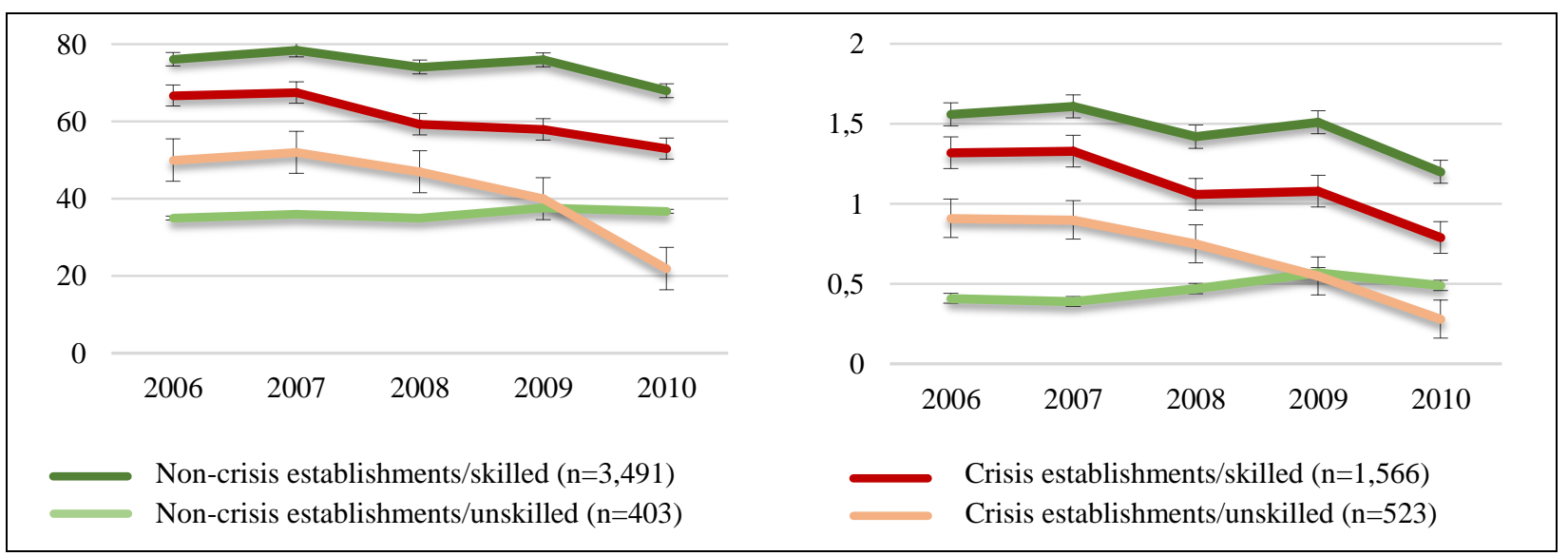

Figure 2: Development of training participation in \% (left) and the number of training measures (right) separated by occupational status in crisis and non-crisis establishments. Standard errors are included

Taking the occupational status of the employees into account in Figure 2, differences in training activities are also evident here. Employees in skilled jobs have a significantly higher probability of participating in training as well as a higher average number of training measures in both crisis and non-crisis establishments. Differences between skill groups are larger in non-crisis than in crisis establishments but converge over time. Considering the training participation of employees in skilled jobs, a stronger negative effect can be observed in crisis establishments, especially in 2008 and 2009. Otherwise, training changes in both establishment groups are comparable. A completely different picture can be seen for the development of training participation among employees in unskilled jobs. Whereas these employees in the non-crisis establishments experience a slight increase in training participation from 2008 to 2009 and a constant participation in 2010, the picture in crisis companies is exactly the opposite. Although they have a higher probability of participating in 
training before the crisis, training participation declines since 2008 and collapses sharply in 2009 and 2010.

The number of training measures for employees in skilled jobs also declines in both crisis and non-crisis establishments, but slightly stronger in crisis establishments from 2008 onwards. For employees in unskilled jobs, the number of training measures in crisis establishments is higher than in non-crisis establishments before the crisis but declines sharply from 2008 onwards. In contrast, the number of training measures for employees in unskilled jobs in non-crisis establishments remains relatively constant over time.

\section{Multivariate analyses}

The regression output in Table 2 shows the determinants of participating in training (model 1) and of the number of training measures (model 2). The main focus of our Diff-inDiff estimations is on the interaction terms of crisis dummy and years, which indicate the effect of the crisis on both training indicators over time.

Table 2: Determinants of training participation and number of trainings

\begin{tabular}{|c|c|c|}
\hline \multirow[t]{2}{*}{ Dependent variable } & $\begin{array}{c}\text { Training dummy } \\
\text { (1) }\end{array}$ & $\begin{array}{c}\text { Number of training } \\
\text { (2) }\end{array}$ \\
\hline & Diff-in-Diff & Diff-in-Diff \\
\hline Crisis * Year 2007 & $\begin{array}{c}-0.001 \\
(0.013)\end{array}$ & $\begin{array}{c}-0.004 \\
(0.029)\end{array}$ \\
\hline Crisis * Year 2008 & $\begin{array}{r}-0.044 \\
(0.032)\end{array}$ & $\begin{array}{r}-0.084 \\
(0.092)\end{array}$ \\
\hline Crisis * Year 2009 & $\begin{array}{c}-0.100 * * * \\
(0.038)\end{array}$ & $\begin{array}{c}-0.215 * \\
(0.114)\end{array}$ \\
\hline Crisis * Year 2010 & $\begin{array}{c}-0.124 * \\
(0.064)\end{array}$ & $\begin{array}{c}-0.301 * * \\
(\mathbf{0 . 1 3 3})\end{array}$ \\
\hline Year 2007 & $\begin{array}{c}0.017 * * \\
(0.008)\end{array}$ & $\begin{array}{c}0.025 \\
(0.020)\end{array}$ \\
\hline Year 2008 & $\begin{array}{c}-0.031^{*} \\
(0.018)\end{array}$ & $\begin{array}{c}-0.164 * * * \\
(0.060)\end{array}$ \\
\hline Year 2009 & $\begin{array}{l}-0.006 \\
(0.021)\end{array}$ & $\begin{array}{l}-0.068 \\
(0.068)\end{array}$ \\
\hline Year 2010 & $\begin{array}{c}-0.136 * * * \\
(0.026)\end{array}$ & $\begin{array}{c}-0.453 * * * \\
(0.069)\end{array}$ \\
\hline Crisis (treatment) & $\begin{array}{c}0.035 \\
(0.027)\end{array}$ & $\begin{array}{l}0.149 * \\
(0.080)\end{array}$ \\
\hline
\end{tabular}




\begin{tabular}{|c|c|c|}
\hline Skilled job & $\begin{array}{c}0.236 * * * \\
(0.026)\end{array}$ & $\begin{array}{c}0.615 * * * \\
(0.061)\end{array}$ \\
\hline Tenure $<10$ years & $\begin{array}{c}0.068 * * \\
(0.032)\end{array}$ & $\begin{array}{c}0.214 * * \\
(0.087)\end{array}$ \\
\hline Tenure $10-20$ years & $\begin{array}{c}0.038 \\
(0.033)\end{array}$ & $\begin{array}{l}0.156 * \\
(0.086)\end{array}$ \\
\hline Experience $<10$ years & $\begin{array}{c}-0.093 * * \\
(0.043)\end{array}$ & $\begin{array}{l}-0.166 \\
(0.128)\end{array}$ \\
\hline Experience $10-20$ years & $\begin{array}{c}-0.014 \\
(0.028)\end{array}$ & $\begin{array}{l}-0.055 \\
(0.086)\end{array}$ \\
\hline Birth year 1952-1961 & $\begin{array}{c}0.076^{* * * *} \\
(0.028)\end{array}$ & $\begin{array}{c}0.201 * * \\
(0.081)\end{array}$ \\
\hline Birth year 1962-1971 & $\begin{array}{c}0.088 * * * \\
(0.030)\end{array}$ & $\begin{array}{c}0.296 * * * \\
(0.092)\end{array}$ \\
\hline Birth year > 1972 & $\begin{array}{c}0.162 * * * \\
(0.042)\end{array}$ & $\begin{array}{c}0.428 * * * \\
(0.126)\end{array}$ \\
\hline Female & $\begin{array}{l}-0.022 \\
(0.019)\end{array}$ & $\begin{array}{c}0.133 * * \\
(0.065)\end{array}$ \\
\hline Employees_199 & $\begin{array}{c}-0.158 * * * \\
(0.026)\end{array}$ & $\begin{array}{c}-0.535^{* * * *} \\
(0.071)\end{array}$ \\
\hline Employees_499 & $\begin{array}{c}-0.052 * * \\
(0.023)\end{array}$ & $\begin{array}{l}-0.066 \\
(0.072)\end{array}$ \\
\hline Western Germany & $\begin{array}{c}0.026 \\
(0.025)\end{array}$ & $\begin{array}{c}0.094 \\
(0.076)\end{array}$ \\
\hline Service sector & $\begin{array}{c}0.144 * * * \\
(0.022)\end{array}$ & $\begin{array}{c}0.487 * * * \\
(0.063)\end{array}$ \\
\hline $\mathrm{R}^{2}$ & 0.093 & 0.096 \\
\hline Observations & 5,983 & 5,983 \\
\hline
\end{tabular}

Dependent variables: training participation (model 1), number of training (model 2); reference category for age: birth year $\leq 1951$; reference category for tenure: tenure $\geq 20$ years; reference category for experience: experience $\geq 20$ years; reference category for occupation status: unskilled job; reference category for establishment size: $\geq$ 500 employees. *Statistically significant at the .10 level; **at the .05 level; *** at the .01 level. Source: WeLLADIAB 2006-2010.

The results for model 1 show no significant Diff-in-Diff effect for the pre-crisis period in 2007. Thus, the identification assumption is fulfilled that, without a crisis, the training behaviour for employees in crisis and non-crisis establishments was the same. As a consequence, the Diff-in-Diff approach identifies the causal recession effect ${ }^{17}$. However, there is a reduction in training participation by $10.0 \mathrm{PP}$ in 2009 and $12.4 \mathrm{PP}$ in 2010 for individuals employed in crisis establishments. Therefore, we find support for the first hypothesis that the crisis of the years 2008 and 2009 reduced training efforts. Significant year dummies in 2008

\footnotetext{
${ }^{17}$ An insignificant Diff-in-Diff coefficient before the treatment also can be called a placebo test. This method serves as an alternative for more data-intensive approaches such as matching (Bellmann et al., 2014).
} 
and 2010 indicate a decline in training participation for employees in all establishments irrespectively of whether they were directly hit by the crisis or not. The insignificant crisis dummy indicates that there are no differences in training participation of employees in the treatment group and the control group beyond the year effects measured by the interaction terms. Furthermore, especially young and employees in skilled jobs and with higher professional experience have a higher training participation. In addition, employees from larger companies and from the service sector tend to participate more in training.

Results for model 2 suggest similar effects of the crisis on the number of training measures. Again, there is a negative effect for employees in all establishments for the years 2008 and 2010. Beyond this effect, significantly negative Diff-in-Diff effects for the years $2009(-0.215)$ and $2010(-0.301)$ indicate that the decline in the number of training measures is greater for employees in crisis establishments than in non-crisis establishments. This finding supports the assumption of the second hypothesis. Effects of further individual and establishment characteristics are similar to the training dummy.

Our results confirm the negative crisis effect on training reported in Popov (2014) and Bellmann et al. (2014). These results however have been derived on the basis of the answers of individual training participants instead of the managers who also indicated whether their firms have been hit by the crisis. In addition to the previous results, we find a negative significant direct crisis effect for the year 2010. The delayed effect of the crisis in 2010 could be a result of the fact that training measures are often planned on a longer-term basis. Many measures may already have been booked at the beginning of the crisis and could not be cancelled or expanded at short notice after the crisis.

In the next step, we analyse whether the impact of the crisis on training activities differs by occupational status. For this purpose, we look at the effects on training participation (Table 3) and on the number of training measures (Table 4) separately for employees in unskilled and skilled jobs. 
Table 3: Determinants of the training participation by occupational status

\begin{tabular}{|c|c|c|c|}
\hline Dependent variable & $\begin{array}{c}\text { Training dummy } \\
\text { Employees in unskilled } \\
\text { jobs (1) } \\
\text { Diff-in-Diff }\end{array}$ & $\begin{array}{c}\text { Training dummy } \\
\text { Employees in skilled } \\
\text { jobs (2) } \\
\text { Diff-in-Diff }\end{array}$ & $\begin{array}{l}\text { Differences } \\
\left.\text { (Chi' }{ }^{2} \text { test }\right)\end{array}$ \\
\hline Crisis * Year 2007 & $\begin{array}{c}\mathbf{0 . 0 5 1} \\
(\mathbf{0 . 0 3 8})\end{array}$ & $\begin{array}{c}-\mathbf{0 . 0 1 4} \\
(0.013)\end{array}$ & $\begin{array}{c}2.68 \\
(0.102)\end{array}$ \\
\hline Crisis * Year 2008 & $\begin{array}{r}-0.054 \\
(0.082)\end{array}$ & $\begin{array}{l}-\mathbf{0 . 0 4 8} \\
(0.036)\end{array}$ & $\begin{array}{c}0.00 \\
(0.946)\end{array}$ \\
\hline Crisis * Year 2009 & $\begin{array}{c}-0.215 * * \\
(0.100)\end{array}$ & $\begin{array}{c}-\mathbf{0 . 0 8 1} * \\
(0.042)\end{array}$ & $\begin{array}{c}1.56 \\
(0.212)\end{array}$ \\
\hline Crisis * Year 2010 & $\begin{array}{c}-0.427 * * * \\
(0.123)\end{array}$ & $\begin{array}{r}-\mathbf{0 . 0 2 4} \\
(0.086)\end{array}$ & $\begin{array}{c}7.40 * * * \\
(0.007)\end{array}$ \\
\hline Year 2007 & $\begin{array}{c}0.002 \\
(0.025)\end{array}$ & $\begin{array}{c}0.020 * * \\
(0.008)\end{array}$ & $\begin{array}{c}0.77 \\
(0.380)\end{array}$ \\
\hline Year 2008 & $\begin{array}{c}-0.017 \\
(0.059)\end{array}$ & $\begin{array}{l}-0.030 \\
(0.019)\end{array}$ & $\begin{array}{c}0.05 \\
(0.828)\end{array}$ \\
\hline Year 2009 & $\begin{array}{c}0.062 \\
(0.072)\end{array}$ & $\begin{array}{l}-0.012 \\
(0.022)\end{array}$ & $\begin{array}{c}0.96 \\
(0.327)\end{array}$ \\
\hline Year 2010 & $\begin{array}{c}0.060 \\
(0.081)\end{array}$ & $\begin{array}{c}-0.156^{* * *} \\
(0.027)\end{array}$ & $\begin{array}{c}6.63 * * * \\
(0.009)\end{array}$ \\
\hline Crisis (treatment) & $\begin{array}{c}0.213 * * * \\
(0.070)\end{array}$ & $\begin{array}{l}-0.019 \\
(0.030)\end{array}$ & $\begin{array}{c}9.54 * * * \\
(0.002)\end{array}$ \\
\hline Tenure $<10$ years & $\begin{array}{l}-0.051 \\
(0.090)\end{array}$ & $\begin{array}{c}0.086 * * \\
(0.034)\end{array}$ & \\
\hline Tenure $10-20$ years & $\begin{array}{c}-0.167 * * \\
(0.081)\end{array}$ & $\begin{array}{c}0.075 * * \\
(0.036)\end{array}$ & \\
\hline Experience $<10$ years & $\begin{array}{l}-0.045 \\
(0.103)\end{array}$ & $\begin{array}{c}-0.104 * * \\
(0.046)\end{array}$ & \\
\hline Experience $10-20$ years & $\begin{array}{l}-0.089 \\
(0.065)\end{array}$ & $\begin{array}{l}-0.017 \\
(0.031)\end{array}$ & \\
\hline Birth year 1952-1961 & $\begin{array}{c}0.006 \\
(0.093)\end{array}$ & $\begin{array}{c}0.084 * * * \\
(0.030)\end{array}$ & \\
\hline Birth year 1962-1971 & $\begin{array}{c}0.025 \\
(0.096)\end{array}$ & $\begin{array}{c}0.098 * * * \\
(0.032)\end{array}$ & \\
\hline Birth year > 1972 & $\begin{array}{c}0.025 \\
(0.112)\end{array}$ & $\begin{array}{c}0.164 * * * \\
(0.044)\end{array}$ & \\
\hline Female & $\begin{array}{c}-0.189 * * * \\
(0.057)\end{array}$ & $\begin{array}{l}-0.012 \\
(0.021)\end{array}$ & \\
\hline Employees_199 & $\begin{array}{c}-0.165^{* *} \\
(0.064)\end{array}$ & $\begin{array}{c}-0.137 * * * \\
(0.029)\end{array}$ & \\
\hline
\end{tabular}




\begin{tabular}{lcc} 
Employees_499 & -0.038 & $-0.044^{*}$ \\
& $(0.059)$ & $(0.026)$ \\
Western Germany & 0.049 & 0.033 \\
& $(0.058)$ & $(0.027)$ \\
Service sector & $0.117^{* *}$ & $0.118^{* * * *}$ \\
\hline $\mathrm{R}^{2}$ & $(0.054)$ & $(0.025)$ \\
Observations & 0.122 & 0.057 \\
\hline
\end{tabular}

Dependent variable: training participation; separate analysis for skill groups; reference category for age: birth year $\leq 1951$; reference category for tenure: tenure $\geq 20$ years; reference category for experience: experience $\geq 20$ years; reference category for establishment size: $\geq 500$ employees. Standard errors based on a robust clusteradjusted sandwich estimator in parentheses; *Statistically significant at the .10 level; **at the .05 level; *** at the .01 level. Source: WeLL-ADIAB 2006-2010.

Table 3 shows that the crisis reduces the probability to participate in training for employees in unskilled jobs additionally by 21.5 PP in 2009 and by 42.7 PP in 2010. In contrast, there is only a slightly negative effect on training participation for employees in skilled jobs of 8.1 PP in the year 2009 and hardly any negative Diff-in-Diff effect in 2010 (2.4 PP, not significant). Furthermore, the $\mathrm{Chi}^{2}$ test indicates that the coefficients of both groups are significantly different in the year 2010. Thus, the findings suggest a stronger negative direct effect of the crisis on training participation for employees in unskilled jobs than for employees in skilled jobs. Therefore, the third hypothesis can be confirmed.

Table 4 shows the impact of the crisis on the number of training measures for employees in unskilled and skilled jobs. As with training participation, the crisis had a significant additional negative effect on the number of trainings for employees in unskilled jobs in $2008(-0.279), 2009(-0.452)$, and especially in $2010(-0.936)$. In contrast, there is a significantly negative Diff-in-Diff effect for employees in unskilled jobs only in 2009 (0.216). Thus, the $\mathrm{Chi}^{2}$ test again suggests significantly different Diff-in-Diff coefficients for the year 2010 for employees in skilled and unskilled jobs. Consequently, the fourth hypothesis can be confirmed. The other individual- and establishment-level determinants for both training indicators are robust to the change in the dependent variable. 
Table 4: Determinants of the number of trainings by occupational status

\begin{tabular}{|c|c|c|c|}
\hline Dependent variable & $\begin{array}{c}\text { Number of trainings } \\
\text { Employees in unskilled } \\
\text { Jobs (1) } \\
\text { Diff-in-Diff }\end{array}$ & $\begin{array}{c}\text { Number of trainings } \\
\text { Employees in skilled } \\
\text { jobs (2) } \\
\text { Diff-in-Diff }\end{array}$ & $\begin{array}{l}\text { Differences } \\
\text { (Chi' }{ }^{2} \text { test) }\end{array}$ \\
\hline Crisis * Year 2007 & $\begin{array}{c}0.071 \\
(0.063)\end{array}$ & $\begin{array}{r}-\mathbf{0 . 0 2 8} \\
(0.032)\end{array}$ & $\begin{array}{c}2.03 \\
(0.155)\end{array}$ \\
\hline Crisis * Year 2008 & $\begin{array}{c}-0.279 * \\
(0.158)\end{array}$ & $\begin{array}{c}-\mathbf{0 . 0 9 1} \\
(0.104)\end{array}$ & $\begin{array}{c}1.00 \\
(0.316)\end{array}$ \\
\hline Crisis * Year 2009 & $\begin{array}{c}-0.452 * * \\
(0.203)\end{array}$ & $\begin{array}{c}-\mathbf{0 . 2 1 6} * \\
(0.128)\end{array}$ & $\begin{array}{c}0.99 \\
(0.320)\end{array}$ \\
\hline Crisis * Year 2010 & $\begin{array}{c}-0.936 * * * \\
(0.228)\end{array}$ & $\begin{array}{l}-\mathbf{0 . 2 4 9} \\
(0.178)\end{array}$ & $\begin{array}{l}5.76 * * \\
(0.016)\end{array}$ \\
\hline Year 2007 & $\begin{array}{c}0.005 \\
(0.037)\end{array}$ & $\begin{array}{c}0.036 \\
(0.022)\end{array}$ & $\begin{array}{c}0.89 \\
(0.346)\end{array}$ \\
\hline Year 2008 & $\begin{array}{l}-0.099 \\
(0.102)\end{array}$ & $\begin{array}{c}-0.186 * \\
(0.106)\end{array}$ & $\begin{array}{l}5.64 * * \\
(0.018)\end{array}$ \\
\hline Year 2009 & $\begin{array}{c}0.194 \\
(0.118)\end{array}$ & $\begin{array}{c}-0.091 \\
(0.074)\end{array}$ & $\begin{array}{l}4.24 * * \\
(0.039)\end{array}$ \\
\hline Year 2010 & $\begin{array}{c}0.129 \\
(0.128)\end{array}$ & $\begin{array}{c}-0.509 * \\
(0.276)\end{array}$ & $\begin{array}{c}18.80 * * * \\
(0.000)\end{array}$ \\
\hline Crisis (treatment) & $\begin{array}{c}0.511 * * * \\
(0.132)\end{array}$ & $\begin{array}{c}-0.065 \\
(0.095)\end{array}$ & $\begin{array}{c}8.57 * * * \\
(0.003)\end{array}$ \\
\hline Tenure $<10$ years & $\begin{array}{c}-0.063 \\
(0.166)\end{array}$ & $\begin{array}{c}0.245^{* *} * \\
(0.098)\end{array}$ & \\
\hline Tenure $10-20$ years & $\begin{array}{c}-0.144 * * \\
(0.155)\end{array}$ & $\begin{array}{c}0.210 * * \\
(0.098)\end{array}$ & \\
\hline Experience $<10$ years & $\begin{array}{l}-0.107 \\
(0.219)\end{array}$ & $\begin{array}{c}-0.131 * * \\
(0.148)\end{array}$ & \\
\hline Experience $10-20$ years & $\begin{array}{c}0.084 \\
(0.129)\end{array}$ & $\begin{array}{l}-0.035 \\
(0.103)\end{array}$ & \\
\hline Birth year 1952-1961 & $\begin{array}{c}0.183 \\
(0.142)\end{array}$ & $\begin{array}{c}0.202 * * \\
(0.089)\end{array}$ & \\
\hline Birth year 1962-1971 & $\begin{array}{c}0.158 \\
(0.138)\end{array}$ & $\begin{array}{c}0.300^{* * *} * \\
(0.103)\end{array}$ & \\
\hline Birth year > 1972 & $\begin{array}{c}0.383 * * \\
(0.193)\end{array}$ & $\begin{array}{c}0.388^{* * * *} \\
(0.143)\end{array}$ & \\
\hline Female & $\begin{array}{c}-0.255^{* *} \\
(0.100)\end{array}$ & $\begin{array}{c}-0.203 * * * \\
(0.074)\end{array}$ & \\
\hline Employees_199 & $\begin{array}{c}-0.408 * * * \\
(0.147)\end{array}$ & $\begin{array}{c}-0.531 * * * \\
(0.082)\end{array}$ & \\
\hline Employees_499 & $\begin{array}{c}-0.018 \\
(0.142)\end{array}$ & $\begin{array}{l}-0.063 \\
(0.085)\end{array}$ & \\
\hline
\end{tabular}




\begin{tabular}{lcc} 
Western Germany & 0.021 & 0.132 \\
& $(0.128)$ & $(0.091)$ \\
Service sector & $0.363^{* * *}$ & $0.450^{* * *}$ \\
\hline $\mathrm{R}^{2}$ & $(0.134)$ & $(0.076)$ \\
Observations & 0.114 & 0.068 \\
\hline
\end{tabular}

Dependent variable: number of training measures; separate analysis for skill groups; reference category for age: birth year $\leq 1951$; reference category for tenure: tenure $\geq 20$ years; reference category for experience: experience $\geq 20$ years; reference category for establishment size: $\geq 500$ employees. Standard errors based on a robust cluster-adjusted sandwich estimator in parentheses; *Statistically significant at the .10 level; **at the .05 level; $* * *$ at the .01 level. Source: WeLL-ADIAB 2006-2010.

\section{Robustness checks}

In order to control whether we find the negative effect of the crisis on employees in unskilled jobs also when we use the full sample with additional interaction terms for employees in skilled and unskilled jobs, a regression equation with triple interaction terms is calculated as a robustness check. More specifically, all four Diff-in-Diff interaction terms $\left(C_{i j} * T^{\prime}{ }_{t}\right)$ are additionally interacted with a binary variable that takes the value of 1 if individuals are in an unskilled job. Thus, the triple interaction terms (Difference-inDifference-in-Differences) in Table A1 in the Appendix imply the additional effects of the crisis for employees in unskilled jobs in comparison to employees in skilled jobs between 2007 and 2010. According to our previous results, we find stronger negative effects of the crisis for employees in unskilled jobs. The crisis reduces the participation of training for employees in unskilled jobs additionally by 14.2 PP in 2009 (not significant) and by 42.9 PP in 2010. Additional negative effects of the crisis for employees in unskilled jobs are also evident in the number of training measures. However, again the triple Diff-in-Diff effect is only significant in $2010(-0.673)$.

In the analyses carried out so far, employees in short-time work have been excluded. As training in the crisis was often offered in conjunction with short-time work (Brenke et al., 2013), establishments' training decisions were probably based on other than the usual costbenefit considerations. In order to ensure that training investments in the crisis were not driven by short-time working arrangements, our last robustness check also includes employees who attended short-time work. The results in Table A2 in the Appendix confirm the previous findings. 


\section{Conclusions}

The objective of this paper is to determine the causal effect of an economic crisis on the training activities of different employee groups. From a theoretical point of view, the effect is unclear because there are arguments for both directions. The few existing empirical studies on the Great Recession indicate a counter-cyclical development of training (Bellmann et al., 2014; Felstead et al., 2012; Mason and Bishop, 2015; Popov, 2014). However, there is no empirical evidence regarding the individual training behaviour of employee groups. Based on a unique German linked employer-employee panel data set, this paper seeks to fill this gap. Using Diff-in-Diff analyses, we avoid endogeneity problems caused by unobservable third factors that otherwise influence both the training activities of the establishment and its probability of being hit by the recession (Hochfellner et al., 2015; Popov, 2014). Furthermore, by separating the source of training data from the source of crisis information, we avoid common method bias. Moreover, the so-called Great Recession in 2008 and 2009 can be seen as an unforeseen, exogenous and time-limited shock. This quasi-experimental setting therefore reveals the causal impact of the crisis on training participation and the number of training measures. In addition, we show that the recession hit training activities of employees in skilled and unskilled jobs differently.

We observe a negative causal effect of the crisis on individual training activities in 2009 and 2010. This reduction in training efforts is especially strong for employees in unskilled jobs. Although there is only a slight negative effect of the crisis on employees in skilled jobs in 2009 , we observe a much greater negative impact for employees in unskilled jobs between 2008 and 2010. The stronger reduction in training opportunities for employees in unskilled or semi-skilled jobs who usually earn less than the employees in the skilled jobs might be one of the reasons for the frequently observed increase in income inequality after recessions (Forster et al., 2011; Grabka, 2015; OECD, 2015). The negative trend in training in the year 2010, which is evident in all groups except for unskilled employees in establishments unaffected by the crisis, shows that the crisis had a lagged effect on training efforts. Training measures are usually booked well in advance and cannot be cancelled at short notice. A lagged recovery of training investments therefore also might be a reason for a sluggish recovery of the economy (Bloom, 2014).

There are some limitations of this paper. First, we only can use a sub-sample of firms in our data set with information on the crisis status, compare Dietz and Zwick (2016). Second, important training information in the data set is not available from all surveys. Therefore, we 
cannot include further training characteristics beyond those included. Third, the data set is limited to certain economic sectors and federal states. Therefore, the representativeness of the results has to be examined critically in future research.

\section{REFERENCES}

Acemoglu, D. and Pischke, J.-S. (1999). Beyond Becker: training in imperfect labour markets. The Economic Journal, 109(453), 112-142.

Aghion, P. and Saint-Paul, G. (1998). Virtues of bad times - interaction between productivity growth and economic fluctuations. Macroeconomic Dynamics, 2(3), 322-344.

Angrist, J. and Pischke, J.-S. (2009). Mostly Harmless Econometrics: an Empiricist's Companion. Princeton University Press, Princeton, NJ.

Antonczyk, D., Fitzenberger, B. and Leuschner, U. (2009). Can a task-based approach explain the recent changes in the German wage structure? Jahrbücher für Nationalökonomie und Statistik, 229(2-3), 214-238.

Arulampalam, W. and Booth A. (2001). Learning and earning: do multiple training events pay? A decade of evidence from a cohort of young British men. Economica, 68(271), 379-400.

Askilden, J. E. and Nilsen, A. (2005). Apprentices and young workers: A study of the Norwegian youth labour market. Scottish Journal of Political Economy, 52(1), 1-17.

Barron, J. M., Black, D. A. and Loewenstein, M. A. (1989). Job matching and on-the-job training. Journal of Labor Economics, 7(1), 1-19.

Barron, J., Berger, M. and Black D. (1997). How well do we measure training? Journal of Labor Economics, 15, 507-528.

Barron, J., Berger, D. and Black, D. (1999). Do workers pay for on-the-job-training? The Journal of Human Resources, 34, 235-252.

Bassanini, A., Booth, A., Brunello, G., De Paola, M. and Leuven, E., (2007), EWorkplace Training in Europe, in Brunello, Garibaldi and Wasmer, (2007), Education and Training in Europe, Oxford University Press.

Bassanini, A., and Brunello, G. (2008). Is training more frequent when the wage premium is smaller? Evidence from the European Community Household Panel. Labour Economics, 15(2), 272-290. 
Bassanini, A. and Ok, W. (2007). How do firms' and individuals' incentive to invest in human capital vary across groups? Working Paper, Organisation for Economic Co-operation and Development, Paris.

Becker, G. S. (1962). Investment in human capital: a theoretical analysis. Journal of Political Economy, 76, 169-217.

Bellmann, L. and Gerner, H. D. (2011). Reversed roles? Wage and employment effects of the current crisis. Research in Labor Economics, 32, 181-206.

Bellmann, L., Gerner, H. D. and Leber, U. (2014). Firm-provided training during the great recession. Jahrbücher für Nationalökonomie und Statistik, 234(1), 5-22.

Bender, S., Fertig, M., Görlitz, K., Huber, M., Hummelsheim, S., Knerr, P., Schmucker, A. and Schröder, H. (2008a). WeLL - Berufliche Weiterbildung als Bestandteil Lebenslangen Lernens. RWI Materialien 45. Essen.

Bender, S., Fertig, M., Görlitz, K., Huber, M. and Schmucker, A. (2008b). WeLL - Unique Linked Employer-Employee Data on Further Training in Germany. Ruhr Economic Papers Nr. 67. RWI Essen.

Bender, S., Fertig, M., Görlitz, K., Huber, M. and Schmucker, A. (2009). WeLL - unique linked employer-employee data on further training in Germany. Schmollers Jahrbuch. Zeitschrift für Wirtschafts- und Sozialwissenschaften, 129(4), 637-643.

Bloom, N. (2014). Fluctuations in Uncertainty, Journal of Economic Perspectives 28(2), 153176.

Blundell, R., Dearden, L. and Meghir, C. (1996). The determinants and effects of work-related training in Britain (No. R50). IFS Reports, Institute for Fiscal Studies.

Blundell, R., Dearden, L., Meghir, C. and Sianesi, B. (1999). Human capital investment: the returns from education and training to the individual, the firm and the economy. Fiscal Studies, 20(1), 1-23.

Bond S., Harhoff, D. and van Reenen J. (2005). Investment, R\&D, and financial constraints in Britain and Germany. Annals of Economics and Statistics, 79/80: 433-460.

Borghans, L., Duckworth, A. L., Heckman, J. J. and Ter Weel, B. (2008). The economics and psychology of personality traits. Journal of Human Resources, 43(4), 972-1059.

Brenke, K., Rinne, U. and Zimmermann K. (2013). Short-time work: The German answer to the Great Recession, International Labour Review, 152 (2), 287-305.

Brunello G. (2009). The effects of economic downturns on apprenticeships and initial workplace training: A review of the evidence. Empirical Research in Vocational Education and Training, 1(1), 145-173. 
Card, D. (1999). The Causal Effect of Education on Earnings. In: Ashenfelter, O., Card, D., (Eds.) Handbook of Labor Economics, Vol. 3A. Amsterdam: Elsevier.

Cohen, W. M. and Levinthal, D. A. (1989). Innovation and learning: the two faces of R\&D. The Economic Journal, 99(397), 569-596.

Dearden, L., Reed, H. and Reenen, J. van (2000). Who gains when workers train? Training and corporate productivity in a panel of British industries, IFS Working Paper 00/04, London.

Dierickx, I. and Cool, K. (1989). Asset stock accumulation and the sustainability of competitive advantage: reply. Management Science, 35(12).

Dietz, D. and Zwick, T. (2016). The Retention Effect of Training - Portability, Visibility, and Credibility, ZEW Discussion Paper 16-011, Mannheim.

Felstead, A. and Green, F. (1996). Training implications of regulation compliance and business cycles. In: Booth, A. L., Snower, D. J., (Eds.) Acquiring Skills. Market Failures, Their Symptoms and Policy Responses. Cambridge: University Press, 255284.

Felstead, A., Green, F. and Jewson, N. (2012). An analysis of the impact of the 2008-9 recession on the provision of training in the UK. Work, Employment and Society, 26(6), 968-986.

Fischer, G., Janik, F., Müller, D. and Schmucker, A. (2008). Das IAB-Betriebspanel-von der Stichprobe über die Erhebung bis zur Hochrechnung.

Forster, M., Chen, W., \& Llenanozal, A. (2011). Divided we stand: Why inequality keeps rising. OECD.

Fouarge, D., Schils, T. and De Grip, A. (2013). Why do low-educated workers invest less in further training? Applied Economics, 45(18), 2587-2601.

Gerlach, K. and Jirjahn, U. (2001). Employer provided further training: Evidence from German establishment data. Schmollers Jahrbuch, 121(2), 139-164.

Grabka, M. (2015). Income and Wealth inequality after the Financial Crisis: The Case of Germany, Empirica, 42(2), 371-390.

Gritz, M. (1993). The impact of training on the frequency and duration of employment. Journal of Econometrics, 57, 21-51.

Hart, R. A. (2005). General human capital and employment adjustment in the Great Depression: apprentices and journeymen in UK engineering. Oxford Economic Papers, 57(1), 169-189. 
Hatch, N. W. and Dyer, J. H. (2004). Human capital and learning as a source of sustainable competitive advantage. Strategic Management Journal, 25(12), 1155-1178.

Heckman, J. (1999). Policies to foster human capital. NBER Working Paper 7288, National Bureau of Economic Research.

Hochfellner, D., Montes, J., Schmalz, M. and Sosyura, D. (2015). Winners and losers of financial crises: evidence from individuals and firms. University of Michigan Working Paper.

Holtmann, A. and Idson, T. (1991). Employer size and on-the-job training decisions. Southern Economic Journal, 58(2), 339-355.

Horning, B. C. (1994). Labor hoarding and the business cycle. International Economic Review, 87-100.

Illeris, K. (2005). Lifelong learning and the low-skilled. International Journal of Lifelong Education, 25, 15-28.

Ivashina, V. and Scharfstein, D. (2010). Bank lending during the financial crisis of 2008. Journal of Financial Economics, 97(3), 319-338.

Knerr, P., Schröder, H., Aust, F. and Gilberg, R. (2012). Berufliche Weiterbildung als Bestandteil Lebenslangen Lernens (WeLL). WeLL-Erhebung 2009. Methodenbericht. Nürnberg.

Knudsen, E. S. and Lien, L. B. (2015). Hire, fire, or train: innovation and human capital responses to recessions. Strategic Entrepreneurship Journal, 9(4), 313-330.

Koberg, C. S. (1987). Resource scarcity, environmental uncertainty, and adaptive organizational behavior. Academy of Management Journal, 30(4), 798-807.

Kuckulenz, A. and Zwick, T. (2005). Heterogene Einkommenseffekte betrieblicher Weiterbildung. Die Betriebswirtschaft, 65(3), 258-275.

López-García, P., Montero, J. and Moral-Benito, E. (2013). Business cycles and investment in productivity-enhancing activities: evidence from Spanish firms. Industry and Innovation, 20(7), 611-636.

Lynch, L. M. (1991). The role of off-the-job vs. on-the-job training for the mobility of women workers. The American Economic Review, 81(2) 151-156.

Majumdar, S. (2007). Market conditions and worker training: How does it affect and whom? Labour Economics, 14(1), 1-23.

Mason, G. and Bishop, K. (2015). The impact of recession on adult training: evidence from the United Kingdom in 2008-2009. British Journal of Industrial Relations, 53(4), 736759. 
Möller, J. (2010). The German labor market response in the world recession - de-mystifying a miracle. Zeitschrift für Arbeitsmarktforschung, 42(4), 325-336.

Moulton, B. (1990). An illustration of a pitfall in estimating the effects of aggregate variables on micro units. The Review of Economics and Statistics, 72(2), 334-338.

OECD. (2015). In it together: Why less inequality benefits all. OECD publishing. Picchio, M. and Van Ours, J. (2013). Retaining through training even for older workers. Economics of Education Review, 32, 29-48.

Popov, A. (2014). Credit constraints and investment in human capital: Training evidence from transition economies. Journal of Financial Intermediation, 23(1), 76-100.

Schmidt, R. H., Hackethal, A. and Tyrell, M. (1999). Disintermediation and the role of banks in Europe: An international comparison. Journal of Financial Intermediation, 8(1-2), $36-67$.

Schmucker, A., Seth, S. and Eberle, J. (2014). WeLL-Befragungsdaten verknüpft mit administrativen Daten des IAB:(WELL-ADIAB) 1975-2011 (No. 201401_de). Institut für Arbeitsmarkt- und Berufsforschung (IAB), Nürnberg. Institute for Employment Research, Nuremberg, Germany.

Sepulveda, F. (2004). Training and business cycles. The Australian National University, Canberra.

Shury, J. (2010). National employer skills survey for England 2009: Key findings report. Evidence Report 13, UK Commission for Employment and Skills, London, UK.

Spengler, A. (2007). The Establishment History Panel. FDZ-Methodenreport, 08/2007.

Stevens, M. (1994). An investment model for the supply of training by employers. The Economic Journal, 104, 556-570.

Westergaard-Nielsen, N. and Rasmussen, A. (1999). Research in Labor Economics, 18, 359375.

Wooldridge, J. (2009). Introductory Econometrics. A Modern Approach (4 ${ }^{\text {th }}$ edition): SouthWestern.

Zwick, T. (2005). Continuing vocational training forms and establishment productivity in Germany. German Economic Review, 6(2), 155-184. 


\section{APPENDIX}

Table A1: Determinants of the training participation and the number of training, triple-Diff-in-Diffestimation

\begin{tabular}{|c|c|c|}
\hline Dependent variable & $\begin{array}{c}\text { Training dummy } \\
\text { (1) } \\
\text { Diff-in-Diff }\end{array}$ & $\begin{array}{c}\text { Number of training } \\
\text { (2) } \\
\text { Diff-in-Diff }\end{array}$ \\
\hline Crisis * Year $2007 *$ Unskilled job & $\begin{array}{c}0.059 \\
(0.041)\end{array}$ & $\begin{array}{c}0.114 \\
(0.071)\end{array}$ \\
\hline Crisis * Year $2008 *$ Unskilled job & $\begin{array}{l}-0.005 \\
(0.089)\end{array}$ & $\begin{array}{l}-0.158 \\
(0.198)\end{array}$ \\
\hline Crisis $*$ Year $2009 *$ Unskilled job & $\begin{array}{l}-0.142 \\
(0.108)\end{array}$ & $\begin{array}{l}-0.225 \\
(0.246)\end{array}$ \\
\hline Crisis * Year $2010 *$ Unskilled job & $\begin{array}{c}-0.429 * * * \\
(0.146)\end{array}$ & $\begin{array}{c}-0.673 * * * \\
(0.264)\end{array}$ \\
\hline Crisis * Year 2007 & $\begin{array}{l}-0.014 \\
(0.013)\end{array}$ & $\begin{array}{l}-0.028 \\
(0.032)\end{array}$ \\
\hline Crisis * Year 2008 & $\begin{array}{l}-0.048 \\
(0.036)\end{array}$ & $\begin{array}{l}-0.091 \\
(0.105)\end{array}$ \\
\hline Crisis * Year 2009 & $\begin{array}{c}-0.081 * \\
(0.042)\end{array}$ & $\begin{array}{c}-0.215^{*} \\
(0.128)\end{array}$ \\
\hline Crisis * Year 2010 & $\begin{array}{l}-0.027 \\
(0.085)\end{array}$ & $\begin{array}{l}-0.262 \\
(0.175)\end{array}$ \\
\hline Crisis * Unskilled job & $\begin{array}{c}0.281 * * * \\
(0.072)\end{array}$ & $\begin{array}{c}0.588 * * * \\
(0.152)\end{array}$ \\
\hline Year $2007 *$ Unskilled job & $\begin{array}{l}-0.022 \\
(0.026)\end{array}$ & $\begin{array}{l}-0.056 \\
(0.043)\end{array}$ \\
\hline Year $2008 *$ Unskilled job & $\begin{array}{c}0.007 \\
(0.062)\end{array}$ & $\begin{array}{c}0.250 * * \\
(0.118)\end{array}$ \\
\hline Year $2009 *$ Unskilled job & $\begin{array}{c}0.068 \\
(0.075)\end{array}$ & $\begin{array}{l}0.271 * \\
(0.139)\end{array}$ \\
\hline Year $2010 *$ Unskilled job & $\begin{array}{c}0.199 * * \\
(0.087)\end{array}$ & $\begin{array}{c}0.609 * * * \\
(0.151)\end{array}$ \\
\hline Year 2007 & $\begin{array}{c}0.020 * * \\
(0.008)\end{array}$ & $\begin{array}{c}0.033 \\
(0.022)\end{array}$ \\
\hline Year 2008 & $\begin{array}{l}-0.032 \\
(0.019)\end{array}$ & $\begin{array}{c}-0.191 * * * \\
(0.066)\end{array}$ \\
\hline Year 2009 & $\begin{array}{l}-0.013 \\
(0.022)\end{array}$ & $\begin{array}{l}-0.096 \\
(0.074)\end{array}$ \\
\hline Year 2010 & $\begin{array}{c}-0.156 * * * \\
(0.027)\end{array}$ & $\begin{array}{c}-0.516 * * * \\
(0.075)\end{array}$ \\
\hline Employee in unskilled job & $\begin{array}{c}-0.391 * * * \\
(0.053)\end{array}$ & $\begin{array}{c}-1.015^{* * *} \\
(0.097)\end{array}$ \\
\hline Crisis (treatment) & $\begin{array}{l}-0.020 \\
(0.028)\end{array}$ & $\begin{array}{c}0.037 \\
(0.090)\end{array}$ \\
\hline
\end{tabular}




\begin{tabular}{lcc} 
Individual characteristics & Yes & Yes \\
Establishment characteristics & Yes & Yes \\
\hline $\mathrm{R}^{2}$ & 0.103 & 0.100 \\
Observations & 5,983 & 5,983 \\
\hline
\end{tabular}

Dependent variables: training participation, number of training measures; separate analysis for skill groups; reference category for age: birth year $\leq 1951$; reference category for tenure: tenure $\geq 20$ years; reference category for experience: experience $\geq 20$ years; reference category for establishment size: $\geq 500$ employees. Standard errors based on a robust cluster-adjusted sandwich estimator in parentheses; *Statistically significant at the .10 level; **at the .05 level; *** at the .01 level. Source: WeLL-ADIAB 2006-2010. 
Table A2: Determinants of the training participation and number of training (sample with short-time workers)

\begin{tabular}{lcc}
\hline Dependent variable: & $\begin{array}{c}\text { Training } \\
\text { participation } \\
\text { Diff-in-Diff }\end{array}$ & $\begin{array}{c}\text { Number of training } \\
\text { Diff-in-Diff }\end{array}$ \\
\hline Crisis * Year 2007 & $\mathbf{0 . 0 0 5}$ & $\mathbf{0 . 0 0 4}$ \\
Crisis * Year 2008 & $\mathbf{( 0 . 0 1 5 )}$ & $\mathbf{( 0 . 0 4 3 )}$ \\
& $-\mathbf{0 . 0 2 4}$ & $\mathbf{- 0 . 0 7 7}$ \\
Crisis * Year 2009 & $\mathbf{( 0 . 0 3 2 )}$ & $\mathbf{( 0 . 0 8 9 )}$ \\
& $-\mathbf{0 . 0 7 5 * *}$ & $\mathbf{- 0 . 2 4 1}$ * $^{* * *}$ \\
Crisis * Year 2010 & $\mathbf{( 0 . 0 3 6 )}$ & $\mathbf{( 0 . 0 8 9 )}$ \\
Crisis (treatment) & $-\mathbf{0 . 1 7 1} * * *$ & $\mathbf{- 0 . 3 4 3 * * *}$ \\
Individual characteristics & $\mathbf{( 0 . 0 4 1 )}$ & $\mathbf{( 0 . 0 9 7 )}$ \\
Establishment characteristics & Yes & Yes \\
\hline $\mathrm{R}^{2}$ & Yes & Yes \\
Observations & Yes & Yes \\
\hline
\end{tabular}

Dependent variables: training participation and number of training measures; separate analysis for experience groups; Further individual characteristics: occupation status, tenure, age, gender; establishment characteristics: size, location, sector. Standard errors based on a robust cluster-adjusted sandwich estimator in parentheses; *Statistically significant at the .10 level; **at the .05 level; *** at the .01 level. Source: WeLL-ADIAB 20062010. 